\title{
Thermal Rejuvenation in Metallic Glasses
}

by

\author{
Junji SAIDA*, Rui YAMADA* and Masato WAKEDA**
}

It is found that metallic glasses can be rejuvenated by a thermal process using experimental and simulation methods. We have reported that an increase in the potential energy, decrease in the density, and change in the local structure as well as mechanical softening were observed after the thermal rejuvenation. We proposed two parameters in the annealing condition of $T_{\mathrm{a}} / T_{\mathrm{g}}$ and $V_{\mathrm{c}} / V_{\mathrm{i}}$ to evaluate the rejuvenation behavior. A rejuvenation map was actually constructed using these two parameters. It is important to satisfy the condition of $T_{\mathrm{a}} / T_{\mathrm{g}} \geq 1.2$ during annealing because of the resetting the thermal history of metallic glasses over $1.2 T_{\mathrm{g}}$ for rejuvenation. The glassy structure changes into a more disordered state by rejuvenation, resulting in the disappearance of icosahedral short-range order (SRO). We also investigated that the rejuvenation occurs partially in a $\mathrm{Zr}_{55} \mathrm{Al}_{10} \mathrm{Ni}_{5} \mathrm{Cu}_{30}$ bulk metallic glass (BMG) when it is annealed at $T_{\mathrm{a}} / T_{\mathrm{g}} \sim 1.07$ followed by rapid cooling. This phenomenon probably originates from disordering in the weakly bonded (loosely packed) region in the heterogeneous local structure model. Such the thermal rejuvenation provides a novel approach for improving the mechanical properties of metallic glasses by controlling their intrinsic glassy structure.

\section{Key words:}

Metallic glass, Rejuvenation, Relaxation, Local structure, Thermal annealing, Mechanical properties

\section{1 緒言}

アモルファス，金属ガラスといった金属系ランダム原 子配列をもつ材料は，これまで人類が長い間用いてきた 規則原子配列をもった結晶構造材料にはない, 高い破断 強度・硬度および低ヤング率を兼社備え, 高耐食性や軟 磁気特性等, 優れた特性を有することが知られている 1$)$. これまで, 上記のランダム原子配列材料は, 結晶のよう な規則原子配列の定義ができないため，一括りで「ラン ダム配列」という表現でしかとらえられてこなかった。 しかし, Fig.1 に示寸模式図のように, 速い冷却速度と遅 い冷却速度で作製したガラス（ランダム原子配列）材料 ではその原子配列の乱雑さに違いがある．前者はより乱 雑（大きな体積をもった未緩和）な状態にあり，後者は 比較的規則化が進んだ（緩和した）状態にある. 理論的 には, 図の低温（室温）側の線を高温側（図の右側）に 外挿して, 液体の体積变化直線との交点に対応する温度 を仮想温度(Fictive Temperature, $T_{\mathrm{f}}$ ) と呼び，その温度が高 いほど高温の液体状態を凍結した, より不規則な構造を 持っているとされている.（Fig.1 では，大きな冷却速度 の仮想温度 $\left(T_{\mathrm{f}}\right.$, fast $)$ は小さい冷却速度のそれ $\left(T_{\mathrm{f}}\right.$, slow $)$ よりも 高い仮想温度を示す. しかし, 実験的にこの仮想温度を 測定（決定）することはきわめて困難である.）

一方著者らは，固体状態の金属ガラスでは，緩和状態 によって例えば熱処理で生成するナノ組織形成 2)や室温 での機械的特性 ${ }^{3)}$ に大きな違いを生じることを報告して
\end{abstract}

いる. 従って, 緩和状態を考えることはランダム原子配 列材料を研究, そして工業的に応用するのにあたって非 常に重要である. 逆に考えれば, ランダム原子配列構造 を “制御” することによって, 特異なナノ組織の形成や 種々の新規物性を発現できる可能性があることを示し ている.

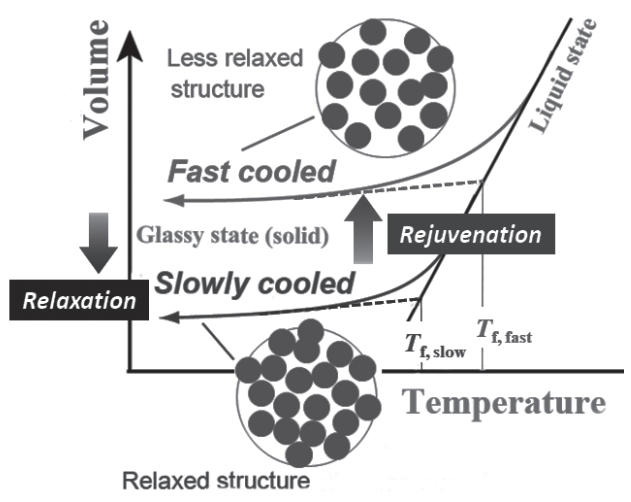

Fig.1 Schematic illustration of glassy structure with cooling rate

例えば，機械的特性で考えてみると，金属ガラスは局 所的な原子群が融解することによって起こる粘性流動 の進展（これを「せん断帯」という）という変形機構の ため, 延性（塑性変形性）に乏しいという久点もあり，

†原稿受理 平成 30 年 8 月 9 日 Received Aug. 9, 2018 C2019 The Society of Materials Science, Japan

* 東北大学 学際科学フロンテイア研究所 テ980-8578 仙台市青葉区荒巻

Frontier Research Institute for Interdisciplinary Sciences (FRIS), Tohoku University, Aoba-ku, Sendai 980-8578.

** 国立研究開発法人 物質・材料研究機構 テ305-0047 つくば市千現

National Institute for Materials Science (NIMS), Sengen, Tsukuba, 305-0047. 
現在この改善が大きな研究課題になっている.未緩和な ガラス状態では自由体積という原子間の空隙がより多 く存在し, それらがせん断帯の起点となって互いにその 進行を阻害することによって，大きな変形能が発現する と考えられている。実際に，未緩和ガラス合金の方が室 温での塑性変形に優れることも明らかとなっている ${ }^{3)}$.

これまで本分野においては, 緩和状態は制御不能なもの であり，一旦金属ガラスが緩和してしまうと，再度溶解 した後, 急冷すること以外に戻すことは不可能であると されてきた。しかしながら，近年本解説にある回復熱処 理, 液体窒素温度への繰り返し冷却 4),5), 強ひずみ加工等 6)-8)によって, 比較的簡便に緩和状態を未緩和状態に遷移 させることができるという報告がなされてきた．このよ うに，一旦緩和状態にあるアモルファス・金属ガラスを 未緩和状態に戻すことを構造若返り (Rejuvenation) とよ び，最近の本分野の大きなトピックスとなっている.

本解説では，主にガラス合金を対象に，ガラス遷移温 度付近の比較的低温での熱処理および冷却による構造 若返り現象を解説し，“原子レベルでの不規則構造の評 価・制御による新材料・新機能創成”という新機軸を提 案することを目的とする.

\section{2 緩和状態の決定因子と熱的構造若返りの考え方}

金属ガラスにおける緩和状態の解析は，本材料が発見 されて以降, 精力的に行われてきた ${ }^{9)}$. その結果，(1)作製 まま（すなわち急冷まま）の材料には多量の自由体積が含 まれており,また原子配列もより乱雑になっている. (2)こ れらを加熱することで, 自由体積の消滅 (密度上昇), 原 子配列の局所的な規則化が進展し，構造緩和と呼ばれる 不可逆な微小発熱反応を生じる. (3)さらに加熱すること でガラス遷移現象を発現し, 過冷却液体状態になって自 由体積の再導入と原子配列の不規則化が進展することが 明らかとなってきた ${ }^{10)}$. Fig.1 に示したように，緩和状態 は，融体から冷却された時の速度によって決定されるこ とがわかっているが, 実際の金属ガラスでは, どの時点の 冷却速度が緩和状態を決定するのか，わかっていなかっ た. 著者らは，金属ガラス作製に用いられる銅鋳型鋳造法 において，雰囲気を変えることでガラス遷移温度 $\left(T_{\mathrm{g}}\right)$ の 1.2 1.3 倍の低温域の過冷却液体の冷却速度を変えること に成功した ${ }^{11)}$ 。こうして作製された金属ガラスを調べて みると，上記の温度域での冷却速度と緩和状態に強い相 関があることを見いだした ${ }^{12)}$. 一方，融点直下の冷却速 度との相関は認められなかった。このことから, 金属ガラ スの緩和状態は，過冷却液体状態の比較的低温域の泠却 速度によって決定されると結論することができた。

このような知見に基づけば，室温での緩和状態は上記 の温度域まで加熱することで，完全にリセットされるこ とが期待される。そしてそこから室温まで冷却される際 の速度に応じて, 新たなガラス構造（緩和状態）が導入さ れることが期待される。つまり, 室温で緩和したガラス構 造であっても, 一旦ガラス遷移温度直上まで加熱後, 急冷
することで未緩和な状態に戻せることを意味しており， 上述した構造若返りが可能であることを示唆するもので ある。

\section{3 熱的構造若返り現象 ${ }^{13), 14}$}

上記のような考察をもとに，実際の金属ガラス試料に おいて構造若返りが可能かどうかを検討してみることと する. その前提として, 緩和状態を評価する方法について 述べる. 既述したように, 緩和状態に対応する原子配列の 乱雑さを示す尺度として仮想温度があげられるが，これ は多くの場合, 理論的解釈で用いられるもので, 実際のガ ラス合金について実験的に決定することは難しい。この ため, 実験では, 求めようとするガラス合金の比熱曲線と, そのガラス合金が完全緩和した状態（通常ガラス遷移温 度まで昇温して徐冷した状態）の比熱曲線の差を積分し たエネルギー量を構造緩和量(Enthalpy of relaxation, $\Delta$ $\left.H_{\text {relax }}\right)$ と呼び，この数值によって緩和状態を評価する.

すなわち, 構造緩和量は以下の式に示すように, 室温 $(\mathrm{RT})$ からガラス遷移温度 $\left(T_{\mathrm{g}}\right)$ まで 2 回の比熱を測定し, 1 回目 $\left(C_{\mathrm{p}, \mathrm{q}}\right)$ と 2 回目 $\left(C_{\mathrm{p}, \mathrm{s}}\right)$ の差の積分で与えられ, その值が大きいほど未緩和なガラスと評価される。

$$
\Delta H_{\text {relax }}=\int_{\mathrm{RT}}^{T_{\mathrm{g}}} \Delta C_{\mathrm{p}}\left(=C_{\mathrm{p}, \mathrm{s}}-C_{\mathrm{p}, \mathrm{q}}\right) \mathrm{d} T
$$

銅鋳型鋳造法を用いて作製した直径 $3 \mathrm{~mm}$ ，長さ $50 \mathrm{~mm}$ の $\mathrm{Zr}_{55} \mathrm{Al}_{10} \mathrm{Ni}_{5} \mathrm{Cu}_{30}$ の円柱状金属ガラス試料を, 厚さ $0.5 \mathrm{~mm}$ に切り出してディスクを用意した. 円柱状金属ガラス試 料では, 切り出す部位によって冷却速度が異なるため, こ れらのディスク試料は種々の緩和状態を有している。こ れらの試料を一旦ガラス遷移温度 $(685 \mathrm{~K})$ まで加熱し, 120 $\mathrm{s}$ 保持して, 完全緩和に近い状態を達成させ, 試料間の構 造状態を統一寸る。なお，この緩和熱処理(Relaxation annealing)での昇温, および降温速度は $0.17 \mathrm{~K} / \mathrm{s}$ とした。

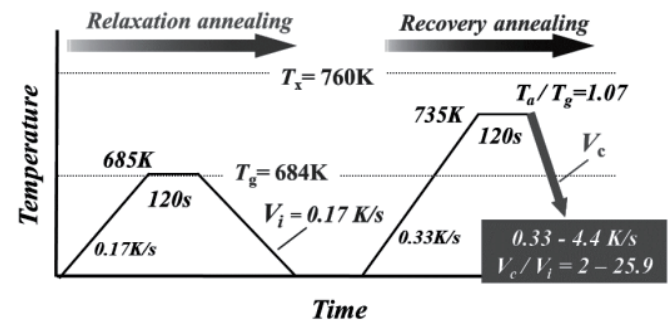

Fig.2 Annealing condition of thermal rejuvenation ${ }^{14}$

それらの試料を $735 \mathrm{~K}$ まで再び加熱し，同じく $120 \mathrm{~s}$ 保 持した後, $0.33 \sim 4.4 \mathrm{~K} / \mathrm{s}$ の泠却速度 (ガラス遷移温度付近 での速度で計測) で室温まで泠却した。この過程を回復熱 処理(Recovery annealing)と呼ぶ. これら一連の熱処理は, 温度制御が正確な入力補償型示差走查熱分析装置(PerkinElmer Pyris Diamond)を用いて行った. この熱処理過程を Fig.2 にまとめて示す. ここで重要なパラメータとして, 回復熱処理時の温度 $\left(T_{\mathrm{a}}\right)$ をガラス遷移温度で規格化した 
温度 $\left(T_{\mathrm{a}} / T_{\mathrm{g}}\right)$ と, 回復熱処理と緩和熱処理時の冷却速度の比 $\left(V_{\mathrm{c}} / V_{\mathrm{i}}\right)$ を設定した。

Fig.3 は銅鋳型鋳造法で作製した試料(as-cast)を緩和 $\left(685 \mathrm{~K}\left(=T_{\mathrm{g}}\right)-120 \mathrm{~s}\right.$, Cooling rate= $\left.\left.0.17 \mathrm{~K} / \mathrm{s}\right)\right)$ させ(Relaxed), それをさらに $735 \mathrm{~K}\left(=T_{\mathrm{g}}+50 \mathrm{~K}\right)-120 \mathrm{~s}$ の熱処理後, $V_{\mathrm{c}} / V_{\mathrm{i}}$ $=10$ および 25.9 で泠却した試料(Recovered)の比熱曲線を 示している. 緩和した試料の比熱曲線は，完全緩和され た 2 回目の測定 $\left(C_{\mathrm{p}, \mathrm{s}}\right)$ の曲線とほぼ一致し, 構造緩和 量は非常に小さい.しかしながら，この緩和材を熱処理 した試料(Recovered)の比熱曲線は，緩和材よりも下方に 位置しており，明らかに大きな構造緩和量を示す．この ことは，回復熱処理によって未緩和状態に回復したこと を示すものである．また $V_{\mathrm{c}} / V_{\mathrm{i}}$ が大きいほど，比熱曲線 は下方に位置していて, より構造若返りが進んでいるこ とを示している。

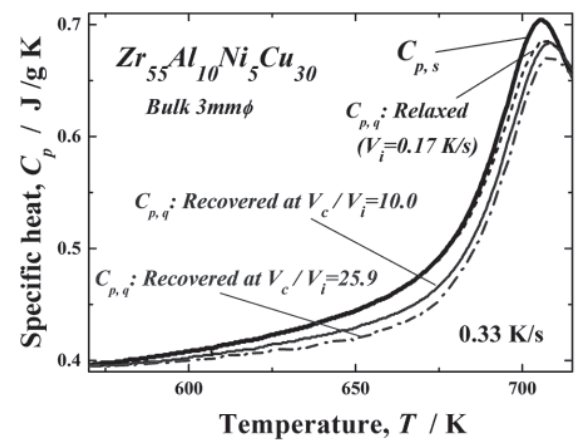

Fig.3 Specific heat curves of relaxed and rejuvenated metallic glass $^{14)}$

Fig.4 は熱処理後の冷却速度 $\left(V_{\mathrm{c}}\right)$ と構造緩和量の関係を 示している. なお図中には, as-castおよび Relaxed 材も 示している．本図からわかるように，一旦緩和した試料 であっても, その後の回復熱処理と大きな冷却速度を確 保することによって Relaxed 材よりも構造緩和量が回復 し，未緩和な状態に戻すことができることが明らかとな った．本実験では，as-cast 材を基準にして，最大 $46 \%$ の 構造緩和量が回復することがわかった。すなわち，当初 の予想どおり，上記の回復熱処理によって構造若返りが 起きることが示された.

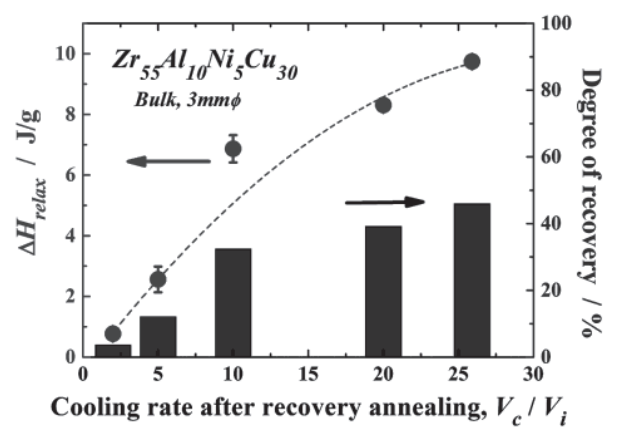

Fig.4 Enthalpy of relaxation and degree of recovery by thermal rejuvenation $^{14)}$
4 熱的構造若返りにともなう特性変化

第 3 章で示したような緩和状態変化は，同時に種々の 特性の変化となって現れる.もっとも予測できる特性と しては密度変化が考えられる。緩和現象は，自由体積の 消滅と原子の局所的配列の規則化であることを考慮す れば, 緩和一構造若返りは直接材料の密度の变化となっ て現れるはずである。Fig.5 は as-cast，Relaxedおよび回 復熱処理 $\left(V_{\mathrm{c}} / V_{\mathrm{i}}=25.9\right)$ 試料(Recovered)の密度変化を示し ている． as-cast 試料は大きな冷却速度に起因した乱雑な ガラス構造のため, 多量の自由体積を含有し, 低い密度 になっている. Relaxed 試料では,このような過剩な自由 体積が消滅し, 密度の増大が認められる.一方, Recovered 試料では再度密度が低下し，新たな自由体積が導入され たことを示している.このような変化は機械的性質にも 表れている. Fig.6 はナノインデンテーション法によって 測定したヤング率と回復熱処理後の冷却速度 $\left(V_{\mathrm{c}} / V_{\mathrm{i}}\right)$ を プロットしたものである. 参考として, Relaxed 材のデー タも示している. Relaxed 材では原子間の空隙が少なく, 変形がより困難になった結果, ヤング率の増大が認めら れる。しかしながら，回復熱処理材においては，冷却速 度の増大によって, より未緩和状態に若返りをすること で自由体積が再導入され，変形に対する抵抗が小さくな ってヤング率が低下する。このような傾向はビッカース

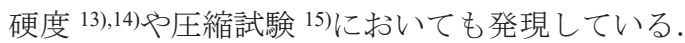

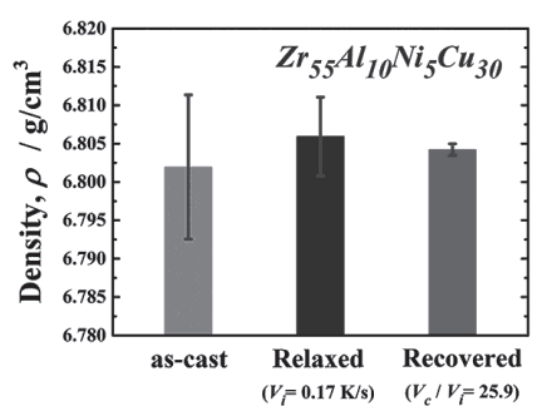

Fig.5 Change in density of as-cast, relaxed and rejuvenated metallic glass $^{14)}$

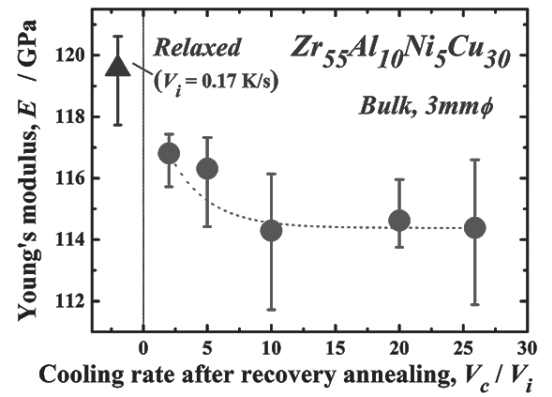

Fig.6 Change in Young's modulus of relaxed and rejuvenated metallic glass ${ }^{14)}$ 


\section{5 シミュレーションによる熱的構造若返りの検証}

以上示したように, 構造若返り現象は熱力学的評価だ けでなく, 力学特性においても大きな変化をもたらすこ とが明らかとなった。このような現象をより深く理解す るにはシミュレーションが有力なツールとなる. LenardJones ポテンシャルモデルを用いて $\mathrm{Cu}_{50} \mathrm{Zr}_{50} 2$ 元系金属 ガラスの構造若返り過程を分子動力学シミュレーショ ンによってモデル化した.この際, モデル原子数は 30,000, 時間ステップは $1 \mathrm{fs}$ とした. シミュレーションでは，液 体状態から $10^{12} \mathrm{~K} / \mathrm{s}\left(V_{\mathrm{i}}\right)$ によって冷却してガラス合金を 作製した後, $10^{13} \mathrm{~K} / \mathrm{s}$ で種々の温度 $T_{a}$ まで加熱して 2000 ps 保持した後, $V_{\mathrm{c}}\left(10^{12} \sim 10^{13} \mathrm{~K} / \mathrm{s}\right)$ の冷却速度で冷却して構 造若返り熱処理を行った。 その後のガラス固体のエネル ギー状態の変化を調べることで緩和状態を評価した。

Fig.7 は構造若返り処理したガラスのポテンシャルエネ ルギー変化を示したものである．横軸は回復熱処理後の 冷却速度で，最初に作製した際の冷却速度 $\left(10^{12} \mathrm{~K} / \mathrm{s}\right)$ で 規格化 $\left(V_{\mathrm{c}} / V_{\mathrm{i}}\right)$ しており, 縦軸も同様に, 最初に作製し た試料のポテンシャルエネルギーで規格化している.

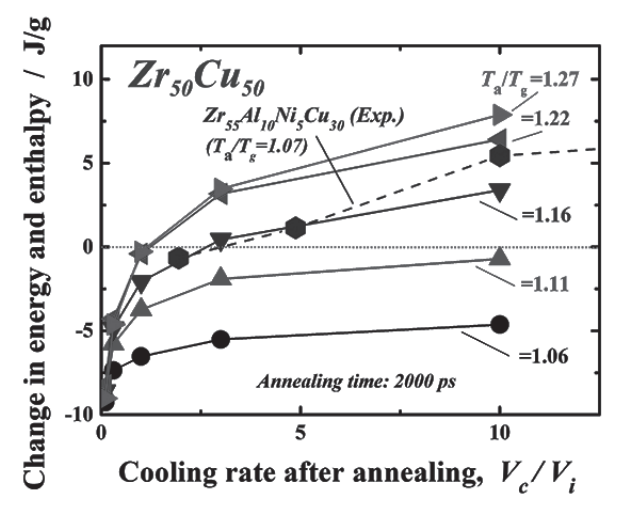

Fig.7 Change in potential energy of $\mathrm{Cu}_{50} \mathrm{Zr}_{50}$ metallic glass by thermal rejuvenation

従って，正のエネルギ一変化を示す場合，よりエネル ギー的に非平衡状態となって構造若返りが起きている ことを示している. 本図では熱処理温度を変えている （ガラス遷移温度で規格化）が, 高い熱処理温度ほど, また冷却速度（ $\left.V_{\mathrm{c}} / V_{\mathrm{i}}\right)$ が大きいほど構造若返りが起きて いることがわかる。このことは，シミュレーションによ っても構造若返り現象をモデル化できていることを示 す結果である，同様の結果は，他の組成においても確認 されている 14),16)

ではその際，構造的にどのようなことが起きているの であろうか? Fig.8 は種々の熱処理温度による構造若返 り処理後のガラス中に含まれる二十面体局所原子配列 (Icosahedral short-range order (SRO))の数を, 数学的多面体 解析によって調べたものである。ここで二十面体は，ガ ラス構造を評価する際に, その構造安定性と密接に関連 する多面体として知られるものである ${ }^{17)}$. 図では, いず れの冷却速度においても，ガラス遷移温度までの加熱に おいては，ほぼ単調に二十面体局所構造の数は増大して
いる.この一連の過程は構造緩和によるもので，既述し たように，自由体積の減少とともに起こる原子の局所的 な規則化によってもたらされた結果である。一方，ガラ ス遷移温度以上まで加熱した場合, 図では $V_{\mathrm{c}} / V_{\mathrm{i}}=0.1 \sim 10$ の範囲で泠却速度を変えて示しているが，構造若返りが 顕著に起きている材料（例えば $V_{\mathrm{c}} / V_{\mathrm{i}}=10$ で $T_{\mathrm{a}} / T_{\mathrm{g}}=1.5 ）$ では，二十面体の数が大きく減少していることがわかる. 逆に, 冷却速度の小さな条件では, 構造緩和によって増 大した二十面体局所構造がほぼ維持されていることも わかる.これらのことから, 構造若返りはガラスの局所 構造の変化とも密接に相関する現象であって, 規則化 （緩和）によって生成した高密度局所構造の消滅をもた らすことが明らかとなった。

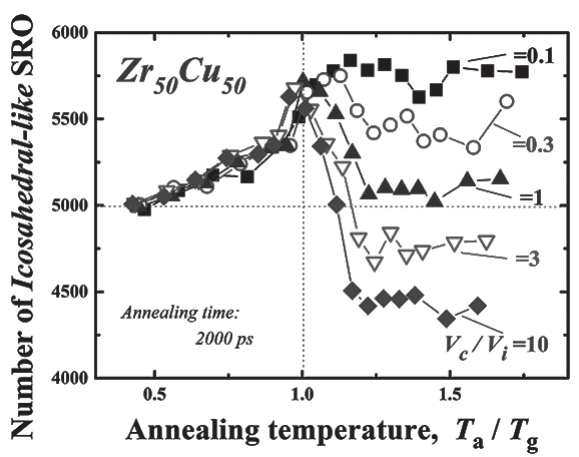

Fig.8 Change in the number of icosahedral-like SRO in $\mathrm{C}_{50} \mathrm{Zr}_{50}$ metallic glass by thermal rejuvenation

\section{6 熱的構造若返りを起こす条件}

構造若返り現象においては, 回復熱処理における冷却 速度比 $\left(V_{\mathrm{c}} / V_{\mathrm{i}}\right)$ と熱処理温度の比 $\left(T_{\mathrm{a}} / T_{\mathrm{g}}\right)$ が重要であるこ とを考察した. Fig.9 は, 種々の合金系における構造若返

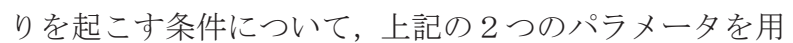
いて整理した構造若返りマップ(Rejuvenation map)を示 したものである。なお，本図は実験およびシミュレーシ ヨンの結果を合わせて図示している. 図の右上部分が構 造若返り(Rejuvenation)を起こす領域である（逆に左下部 分が, 緩和(Relaxation)が進行する領域).この図から, 緩 和と構造若返りがどのような条件で進行するのかが明 らかである。大きな冷却速度と高い熱処理温度が若返り に適しているが，例えば， $V_{\mathrm{c}} / V_{\mathrm{i}}>1 ， T_{\mathrm{a}} / T_{\mathrm{g}}>1.2$ が両者の 現象を分ける一つの目安である.ただ分子動力学シミュ レーションでは，ある種理想的な高速加熱冷却なので, ガラス構造が大きく崩れることはないが, 本解説では詳 しくは述べないが，実際の試料では熱処理温度を高くす ることで結晶化が進行するという問題もある。これは緩 和時間および結晶化キネティックスの時間スケールが 実験では大きく問題となるためである。そのため, シミ ユレーション結果よりも低い温度域での回復熱処理が 必須になってくる. 実際, 既述した実験では $1.07 T_{\mathrm{g}}$ 付近 での熱処理によって構造若返りを起こしている. また加 えて，このような構造若返り条件は合金系によって違い 
があるのかどうか，今後検討していく必要がある．特に 金属ガラスのフラジリティは構造不均一性と大きく関 わってきていて，次節で述べるように若返り機構と密接 に関連していると考えられる。

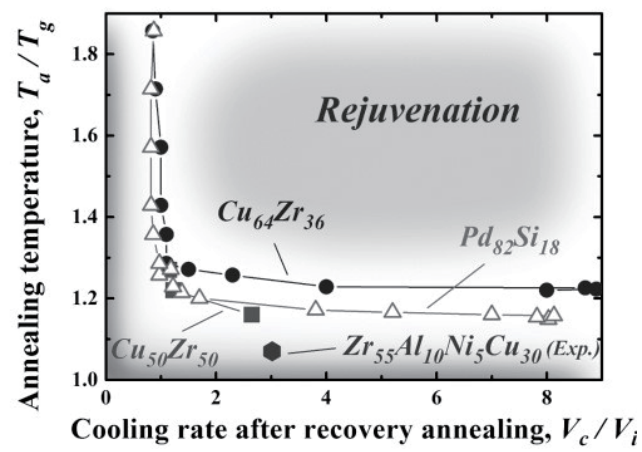

Fig.9 Thermal rejuvenation map of metallic glasses ${ }^{14)}$

\section{7 熱的構造若返りの機構}

構造若返りは，ガラス中に均一に起こるのか，また局 所的に起こるのかというメカニズムの解明は，本研究に とって非常に重要な観点である。このような緩和，若返 り（回復）現象を考察するため，動的粘弾性測定装置を 用いて，損失弾性率の温度変化を調べた．Fig.10 は作製 まま (as-quenched)，緩和 (Relaxed) および若返り (Rejuvenated)試料の結果である。なお測定は $1 \mathrm{~Hz}$ の周波 数である。緩和挙動には高温側から $\alpha$-relaxation, $\beta$ relaxation... といくつかのモードがある。緩和，若返り 試料のいずれも $684 \mathrm{~K}$ 付近の $\alpha$-relaxation の值が asquenched 試料の值と変化しなかったことに対して, $600 \mathrm{~K}$ 付近の $\beta$-relaxation では值が顕著に変化を示している.す なわち, as-quenched 試料から緩和によってシグナル強度 が低下した状態が，若返りによって as-quenched 試料側 一復活している。このことから，粘弾性的にも回復熱処 理によって構造が若返っていることが示され，その挙動 が主に $\beta$-relaxation 周辺で見られていることがわかる. $\beta$ relaxation は低温で見られる緩和で, ガラスの不均一性と 相関する，単原子の小規模ジャンプが主たる現象である と言われている 18)-21)。金属ガラスでは，比較的動きやす い領域（弱結合領域，Weakly Bonded Region (WBR)）と 比較的動きにくい領域（強結合領域, Strongly Bonded Region (SBR)）で構成される不均一局所構造モデルが提 唱されている ${ }^{22)}$. $\beta$-relaxation はこのモデルでは WBR で 起こることが考察されている ${ }^{23)}$. 従って, 若返り熱処理 による構造緩和によって，主にWBR から自由体積が消 滅し，その後，過冷却液体状態に昇温して急冷すること でWBRに自由体積が再導入されることで, その領域 ( $\beta$ relaxation 領域) の原子配列が乱雑化して若返りが達成さ れていると考えられる。しかし, 若返り試料(Rejuvenated) は作製まま(as-quenched)に比べると $\beta$-relaxation の回復は わずかである。このことは，若返りさせた条件が $1.07 T_{\mathrm{g}}$ 付近と低く，これによって導入されるガラス構造の仮想
温度 $\left(T_{\mathrm{f}}\right)$ が，作製ままに比べて相当に低いことが推測さ れる。もし，本実験よりさらなる急速昇温と急速冷却が 可能な装置があり，より高い温度で若返り熱処理ができ れば，より高い仮想温度を有する乱雑なガラス状態に回 復できるのではと考えられる。ただ，このような考察は まだ十分でなく，今後不均一性がより発達した Pd 系な どの他の合金系での考察を含め，種々の観点からの検討 が必要である。また，本手法による構造若返りを行って も，結晶化に対する安定性は改善されないこともわかっ ている 24)。この理由はまだ明らかになっていないが， 金属ガラスの構造不均一性を考慮すると, 若返り熱処理 によって, 新たな乱雑性が導入される領域と局所的に結 晶化に向けた規則化が進行する領域の 2 つが同時に存 在していると推察される. 既述したモデルに従えば, SBR として代表的な二十面体局所構造は, 若返りによっ て減少することが Fig.8 の MD シミュレーションから考 察されているので, SBR の部分が結晶化へと進展し, WBR の部分が若返りへと構造遷移しているのではと考 えられる。

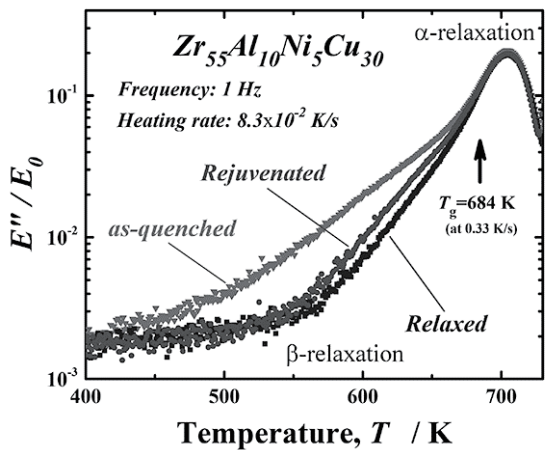

Fig.10 Internal losses in as-quenched, relaxed and rejuvenated $\mathrm{Zr}_{55} \mathrm{Al}_{10} \mathrm{Ni}_{5} \mathrm{Cu}_{30}$ metallic glass ribbon samples ${ }^{14}$ )

\section{8 結 言}

これまで金属ガラスにおける緩和は，ほぼ不可逆の現 象と見なされており，その過程を考察することはあって も，積極的に構造制御として未緩和状態に回復させる

(構造若返り) ことが検討されたことは無かった。ここ で紹介した金属ガラスの熱的構造若返りは，金属ガラス の新たな構造制御手法を提案し，加工や成形による構造 緩和によって失われた塑性変形性の回復という知見を もたらすことから，その重要性は自明である．また基礎 物性の観点からも，第 7 章で述べたように，本現象は金 属ガラスの局所構造不均一性を基本に考えなければな らず，その本質に迫る課題をはらんでいると考えられる. 実際に，直近の 2018 年 6 月に韓国ソウルで開催された バルク金属ガラス国際会議(BMG XII)において，金属ガ ラスの構造若返り (Rejuvenation)はホットトピックスと して多くの発表と聴衆を集めるに至った。今後，国内外 で本現象の研究，考察が進展し，多くの新たな知見が創 出されることが期待される. 
本研究は, 大阪大学大学院基礎工学研究科 尾方成 信教授, 中国華中科技大 郭威博士等との共同研究の成 果です。また本研究の遂行にあたっては, 文部科学省科 学研究費補助金 基盤研究 A (No.23246109)および東北 大学学際科学フロンティア研究所 学際研究促進プロ グラム「ランダム原子配列構造制御の基礎科学と新材 料・新機能創成への融合展開」の支援を得ました。ここ に記して謝意を表します。

\section{参 考 文 献}

1) E.g., C. Suryanarayana and A. Inoue, "Bulk metallic glasses", CRC Press, Boca Raton, (2010).

2) J. Saida, A.D. Setyawan and E. Matsubara, "Effect of relaxation state on nucleation and grain growth of nanoscale quasicrystal in Zr-based bulk metallic glasses prepared under various cooling rates", Applied Physics Letters, Vol.99, 061903 (2011).

3) J. Saida, A.D. Setyawan, H. Kato, M. Matsushita and A. Inoue, "Plastic deformation by glassy structure control in $\mathrm{Zr}-\mathrm{Al}-\mathrm{Ni}$ Cu-based BMGs", Journal of Alloys and Compounds, Vol.504S, pp. S52-55 (2010).

4) S.V. Ketov, Y.H. Sun, S. Nachum, Z. Lu, A. Checchi, A.R. Beraldin, H.Y. Bai, W.H. Wang, D.V. Louzguine-Luzgin, M.A. Carpenter and A.L. Greer, "Rejuvenation of metallic glasses by non-affine thermal strain", Nature, Vol. 524, pp.200-203 (2015).

5) W. Guo, R. Yamada and J. Saida, "Rejuvenation and plasticization of metallic glass by deep cryogenic cycling treatment", Intermetallics, Vol.93, pp.141-147 (2018).

6) F.O. Méar, B. Lenk, Y. Zhang and A.L. Greer, "Structural relaxation in a heavily cold-worked metallic glass", Scripta Materialia, Vol.59, pp.1243-1246 (2008).

7) A. Concustell, F.O. Méar, S. Surinach, M.D. Baro and A.L. Greer, "Structural relaxation and rejuvenation in a metallic glass induced by shot-peening", Philosophical Magazine Letters, Vol.89, pp.831-840 (2009).

8) F. Meng, K. Tsuchiya, S. Ii and Y. Yokoyama, "Reversible transition of deformation mode by structural rejuvenation and relaxation in bulk metallic glass", Applied Physics Letters, Vol. 101, 121914 (2012).

9) H.S. Chen, "On mechanisms of structural relaxation in a $\mathrm{Pd}_{48} \mathrm{Ni}_{32} \mathrm{P}_{20}$ glass", Journal of Non-Crystalline Solids, Vol.46 pp.289-305 (1981).

10) O. Haruyama, Y. Nakayama, R. Wada, H. Tokunaga, J. Okada, T. Ishikawa and Y. Yokoyama, "Volume and enthalpy relaxation in $\mathrm{Zr}_{55} \mathrm{Cu}_{30} \mathrm{Ni}_{5} \mathrm{Al}_{10}$ bulk metallic glass", Acta Materialia, Vol.58, pp.1829-1836 (2010).

11) A.D. Setyawan, H. Kato, J. Saida and A. Inoue, "Glass formation dependence on cast-atmosphere pressure in $\mathrm{Zr}_{65} \mathrm{Al}_{7.5} \mathrm{Ni}_{10} \mathrm{Cu}_{17.5-\mathrm{x}} \mathrm{Pd}_{\mathrm{x}}(\mathrm{x}=0-17.5)$ alloy system: A resultant effect of quasicrystalline phase transformation and cooling mechanism during mold-casting process", Journal of Applied Physics, Vol.103, pp. S044907 1-8 (2008).

12) J. Saida, A.D. Setyawan, H. Kato and A. Inoue, "Cooling process and cast structure of $\mathrm{Zr}-\mathrm{Al}-\mathrm{Ni}-\mathrm{Cu}$ metallic glasses produced by various atmosphere", Metallurgical and Materials Transactions A, Vol.42A, pp. 1450-1455 (2011).
13) J. Saida, R. Yamada and M. Wakeda, "Recovery of less relaxed state in $\mathrm{Zr}$-Al-Ni-Cu bulk metallic glass annealed above glass transition temperature", Applied Physics Letters, Vol.103, 221910 (2013).

14) J. Saida, R. Yamada M. Wakeda and S. Ogata, "Thermal rejuvenation in metallic glasses", Science and Technology of Advanced Materials, Vol.18, pp.152-162 (2017).

15) W. Guo, R. Yamada, J. Saida, S. Lu and S. Wu, "Thermal rejuvenation of a heterogeneous metallic glass", Journal of Non-Crystalline Solids, Vol. 498, pp.8-13 (2018).

16) M. Wakeda, J. Saida, J. Li and S. Ogata, "Controlled rejuvenation of amorphous metals with thermal processing", Scientific Reports, Vol. 5, 10545 (2015).

17) D.B. Miracle, A.L. Greer and K.F. Kelton, "Icosahedral and dense random cluster packing in metallic glass structures", Journal of Non-Crystalline Solids, Vol.354, pp.4049-4055 (2008).

18) T. Ichitsubo, S. Yukitani, E. Matsubara and H. Kato, "Study on correlation between complex relaxation phenomena and elastic heterogeneity in metallic glasses", Journal of the Society of Materials Science, Japan, Vol.62, pp.167-171 (2013).

19) O. Haruyama, H. Sawada, K. Yoshikawa, T. Kawamata, Y. Yokoyama and K. Sugiyama, "Static measurements of $\alpha$ - and $\beta$-relaxations in Zr-based bulk metallic glasses", Journal of the Japan Society of Powder and Powder Metallurgy, Vol.60, pp.217-223 (2013).

20) H. Kato, T. Ichitsubo, H. Wang and T. Wada, "Dynamic relaxation of $\mathrm{Pd}_{42.5} \mathrm{Ni}_{7.5} \mathrm{Cu}_{30} \mathrm{P}_{20}$ metallic glass", Journal of the Japan Society of Powder and Powder Metallurgy, Vol.60, pp.228-235 (2013).

21) F. Zhu, H.K. Nguyen, S.X. Song, D.P.B. Aji, A. Hirata, H. Wang, K. Nakajima and M.W. Chen, "Intrinsic correlation between $\beta$ relaxation and spatial heterogeneity in a metallic glass", Nature Communications, Vol.7, 11516 (2016).

22) T. Ichitsubo, E. Matsubara, H.S. Chen, J. Saida, T. Yamamoto and N. Nishiyama, "Structural instability of metallic glasses under radio-frequency-ultrasonic perturbation and its correlation with glass-to-crystal transition of less-stable metallic glasses", The Journal of Chemical Physics, Vol.125, 154502 (2006).

23) T. Ichitsubo, E. Matsubara, T. Yamamoto, H.S. Chen, N. Nishiyama, J. Saida and K. Anazawa, "Microstructure of fragile metallic glasses inferred from ultrasound-accelerated crystallization in Pd-based metallic glasses", Physical Review Letters, Vol.95, 245501 (2005).

24) R. Yamada, N. Tanaka and J. Saida, "Crystallization behavior of thermally rejuvenated $\mathrm{Zr}_{50} \mathrm{Cu}_{40} \mathrm{Al}_{10}$ metallic glass", Materials Transactions, Vol.58, pp.1463-1468 (2017). 